\title{
New Rural Development and Hierarchical Governance in Vietnam: Impacts of government support on rural households' income using a Hierarchical Linear Modelling
}

\author{
Manh Hung Do', Sang Chul Park ${ }^{2}$ \\ 1 Southern Centre for Agricultural Policy, Institute of Policy and Strategy for Agriculture and Rural \\ Development, Ho Chi Minh City, Vietnam \\ ${ }^{2}$ College of Political Science and Public Administration, Yeungnam University, Gyeongbuk Province, South \\ Korea
}

\begin{abstract}
The New Rural Development (NRD) program is one of the most important policies in agriculture and rural development of Vietnam by 2020. In the period of $2010-2015$, the government mobilized about 851,380 billion Vietnam Dong (VND) (approximately US\$38.7 billion) for investments in rural development projects across the country. Among the top priorities, solving a broadening income and poverty gap between urban and rural areas, between leading and lagging regions, and among ethnic groups are one of the most essential issues. This research paper is targeted to provide an empirical evidence for answering the question whether the government assistance could effectively and positively impact on rural households' income through the NRD program by using a hierarchical linear modelling (HLM). The results of the mixed effect model could firmly reveal that the financial assistance could positively influence on rural households' income through investments in roads, income generation models, and technical trainings.
\end{abstract}

\section{Keywords}

Hierarchical Governance, Multilevel Analysis, Hierarchical Linear Modelling, New Rural Development, Vietnam.

Do, M. H. and Park, S. Ch. (2018) "New Rural Development and Hierarchical Governance in Vietnam: Impacts of government support on rural households' income using a Hierarchical Linear Modelling", AGRIS on-line Papers in Economics and Informatics, Vol. 10, No. 4, pp. 3-15. ISSN 1804-1930. DOI 10.7160/aol.2018.100401.

\section{Introduction}

Since the economic and political reform in 1986 (the Doi Moi), Viet Nam's economy has transformed positively and significantly from an impoverished and closed economy into an open socialist-oriented market economy. Consequently, the annual growth rate since 1990 has been among the fastest countries in the world with an average of $5.5 \%$ in $1990 \mathrm{~s}$ and $6.4 \%$ in the 2000s. Recently, Vietnam's economy continued to accelerate in 2015 with an estimated GDP growth rate of $6.7 \%$ and became a member of the lower middle-income group in 2010 (The World Bank, 2018). However, the current situation shows that the nation is now facing numerous challenges such as slowing down economic growth, over exploitation of natural resources, and, especially, an unbalanced development between urban and rural regions up to nearly $50 \%$ between the two regions (GSO, 2016).

The dramatic change of Vietnam's economy towards modernization and urbanization process created a biased development between the urban and rural regions that the rural areas are homes of more than $70 \%$ of Vietnam's population and about $92 \%$ of poor households living on about $\$ 0.50$ a day (GSO, 2010). Moreover, the rural regions in Vietnam are also a combination of large majority of the population, poor households, and ethnic groups. Poverty and low levels of education are among the factors of social vulnerability beside population growth, gender inequality, fragile and hazardous locations, and lack of access to resources and services, including knowledge and technological means, disintegration of social patterns (Damas and Israt, 2004).

As a result, there are some critical issues 
in rural communities such as a wider income gap with urban areas, a poor rural institution for agriculture and rural development, poor living conditions and infrastructure in rural areas, and unsustainable farming methods which could negatively impact on the local environment and human health. Among them, solving a broadening income and poverty gap between urban and rural areas, between leading and lagging regions, as well as among 54 ethnic groups is one of the most essential issues. This is crucial not only in Vietnam, but also in any developing countries.

In order to resolve the above critical issues, the Prime Minister of Vietnam issued the Decision No. 800/QĐ-TTg dated 04/06/2010 to approve the National program of New Rural Village Development between 2010 and 2020. Later, the government replaced the policy by the Decision No. $1600 /$ QĐ-TTg dated $16 / 08 / 2016$ to renew the National program of the New Rural Village Development for the period of 2015-2020. The main purposes of the new policy are to encourage and mobilize a revolutionary campaign to improve local infrastructures, living conditions, comprehensive development of productionrelated activities, attach agricultural development with industrial development in rural regions, as well as increase income, and improve physical and mental health of people living in rural communities. The specific objectives of the program by 2020 will be aimed at (i) ensuring the percentage of communes achieved "New Village Standard" at 50\% (varying from region to region); (ii) improving rural infrastructures for production and living such as roads, electricity access, water supply, educational and medical facilities, and (iii) improving rural households' living conditions and developing production models in commercial manner to create stable jobs and increase households' income of at least 1.8 times higher than that of 2015 .

Rural development or rural community development is so complex, across several sectors, and involves various policies and actions that have direct or indirect impacts on the rural areas and the livelihood of the rural people (Rudengren et al., 2012). Particularly, rural development will not only involve farmers or non-farming households, cooperatives, production groups, but it also includes civil organizations, central and local governments, both private and public sectors. In the case of Vietnam, rural development is even more difficult and sensitive than other countries because most of the population and minority groups
(54 minorities) are living in rural regions. Therefore, rural development might make a huge impact on social, political, and economic perspectives of rural communities.

Besides, rural development is not a new concept, however new approaches and methodologies for rural community improvement keep changing and updating to follow the changes of global development. Saemaul Undong, a famous rural development program of South Korea in 1970s, is gradually adapting and becoming a global model and an exemplary of Vietnam's rural development program. Sooyoung (2009) pointed out that government's in-kind support was one of the successful factors of Saemaul Undong which effectively helped increase rural households' income and improve living conditions. In the Saemaul movement, South Korea's government provided in-kind support such as cement, steel, fertilizers... to local communities to ignite people's awareness of community development and, significantly contributed to the development of rural community and better households' income (Cho and Kim, 1991). Between 2010 and 2015, the government mobilized up to 851,380 billion Vietnam Dong (VND) (approximately US\$38.7 billion; US\$ $1 \sim 22,000$ VND) for investments in rural development projects across the country such as infrastructure constructions, technical supports, and income generation models (Economic Committee, 2016).

The implementation of the NRD program apparently shows a hierarchical governance structure and effectively disseminates the NRD as an innovation throughout the country (Manh et al., 2016). Generally, this NRD program is a top-down policy flowing hierarchically from the central government to local governments. One of the advantages of hierarchical rules is that they can resolve commitment problems through the formal rule structure and shape the agreement between state and local governments (Sang-Chul et al., 2012). Since the NRD is still implementing, researchers and policy-makers might be wondering whether the government's support could actually have a positive impact on the rural communities or help improve living conditions by investing in infrastructure, providing assisting projects, and improving human resources in rural regions. This is a foundation for applying a Hierarchical Linear Modelling (HLM) to assess the relationship between factors at provincial levels and factors at communal levels. 
The HLM or multilevel analyses were widely used in algorithm development (Dempster et al., 1977), social studies and psychology (Paterson and Goldstein, 1991; Woltman et al., 2012), commercial aviation (Beaubien et al., 2001), and land uses and housing (Sang-Chul et al. 2012). Especially, in the field of health and medical studies, Keon-Hyung et al., (2013) examined factors affecting medical costs, medical practices... between hospitals (Level 2) and patients (Level 1) using nested data with HLM approach. Besides, Rice and Leyland (1996) and Rice and Jones (1997) emphasized HLM's significance in health economics research. More popularly, the HLM was applied to estimate the impacts of teaching methods, teachers' instruction, and principal characteristics... on classes' or students' performance in the field of education effects research (Raudenbush and Bryk, 1986; Garner and Raudenbush, 1991; Lee et al., 1991; Raudenbush et al., 1991; Ma, X. and Klinger, D. A., 2000; Desimone et al., 2002; Marks, H. M. and Printy, 2003). However, thus far, there has a few studies researching on the impacts of government policies at local levels, particularly the relationships between central and local governments, between local government and local communities in rural development and agricultural policies in developing countries.

Hence, this research paper is targeted to provide an empirical evidence for justifying whether the government' budget for rural development (Level 2) could effectively and positively impact on rural households' income (Level 1) through the NRD program by using a multilevel analysis. The paper would play an important role in providing evidence and implications to significantly contribute to the implementation of the NRD program in Vietnam in the next period of 2016 - 2020. Besides, findings from this paper could be used for recommending effective and efficient investments in rural community development and benchmarking with other developing countries that are currently implementing rural development programs. More importantly, this research paper could be considered as the first trial for estimating multilevel effects of government's assistance on rural households' income using a HLM.

\section{Materials and methods}

\section{Research method}

In general, analytical strategies used to deal with multilevel data could be aggregation or disaggregation methodologies. However, there are some critical problems using these two methods. While aggregated models ignore within group variance and aggregated lower level variables with higher levels, disaggregated models ignore between group variance and disaggregated higher-level data with lower levels (Keon-Hyung et al., 2013). In this case, multilevel analysis (or Hierarchical Linear Modelling) which simultaneously analyses both within and between group variances can help eliminate the loss of information. Besides, Keon-Hyung et al. (2013) also concluded that applying hierarchical modeling will be more powerful in treating multilevel variables (for example Medicaid inpatient expenditure within patients' and hospitals' groups) than aggregated or disaggregated modeling.

The HLM is a complex form of ordinary least squares (OLS) regressions used to estimate the variance of outcome (dependent) variables when predictor (independent) variables vary hierarchically from level to level by taking multilevel regression relationships into estimations. Moreover, the HLM can accurately investigate multilevel data's relationships and disentangle between and within group variance's effect. In the HLM, the effect size and standard errors are not distorted and it also retained the potentially meaningful variance estimated by aggregation or disaggregation methods (Beaubien et al., 2001; Gill, 2003; Osborne, 2000). As a result, using HLM is considered as a preferred method for nested data because it requires a fewer number of assumptions than other statistical and analytical methods (Raudenbush and Bryk, 2002) and, especially, it could help prevent researchers' analysis from facing a Type-I error (Huta, 2014).

\section{Research data}

The paper will rely on the data of Vietnam Households Living Standard Survey (VHLSS) which is conducted every 2 years with the newly published and updated version in 2014 (the 2016 data has not officially published yet). The data of this survey is one of the most reliable sources of analyzing social aspects in Vietnam. Basically, the survey is conducted at the households and communal levels with scientific sampling and professional interviews. While the communal questionnaire is aimed at collecting social - economic information, that of households is detailed in gathering households' aspects and mostly covered income and expenditure 
of each household. The total numbers of respondents are 9,399 households and 1,716 communes. Due to the availability of the data, this research paper will employ a multilevel analysis using the data of 1,226 communes representing 34 provinces and cities from different geographical regions across the country (Table 1).

In this multilevel analysis, the unit of analysis is local communities (communes) and the only outcome variable (dependent variable) is the average households' income. At level 1, there are geographical location, government's assistance, extension service, and road network representing internal and external resources for community development. These independent variables denote the second objective of the NRD which is aimed at improving rural infrastructures for production and living to raise rural households' income level (spontaneously is the dependent variable and the third objective of the program). These level 1 variables are identified by the level 2 cluster variable which is local government budget (at provincial level) in a multilevel model. This model can accurately estimate lower level-1 slopes and their implementation in estimating higher-level outcomes by taking both the level-1 and level-2 regression relationships into account (Table 2).

\section{Model specification}

Multilevel models or hierarchical linear models are also known as linear mixed-effects models which includes fixed effects and random effects. In other words, mixed effect models are a generalization of conventional linear regression which can include random deviations (the so-called "effects") rather than the overall error term (StataCorp, 2015). On the one hand, the fixed effects denote a variable's discrete, intentionally elected,

\begin{tabular}{|l|l|l|}
\hline Hierarchical level/Variables & Denotation & Description and Measurement \\
\hline Level 2 - Local government (Provincial level) \\
\hline Governments' budget & BUDGET & $\begin{array}{l}\text { Governments' budget for the NRD program including both central and local } \\
\text { government budgets, and other types of reciprocal capital of villagers } \\
\text { from 2010 - 2014; Billion VND. }\end{array}$ \\
\hline Level 1 - Local communities (Communal level) \\
\hline Dependent/Outcome variable \\
\hline Households' income & INCOME & Average households' income at communal level in 2014; Thousand VND. \\
\hline Independent variable & GEO & Geographical location; dummy variable: Delta region = 1, other regions =0 \\
\hline Geographical location & GOVTPRO & $\begin{array}{l}\text { Government provision of economic development program and projects } \\
\text { in the last 3 years; dummy variable: Yes = 1, No = 0 }\end{array}$ \\
\hline Government's assistance & EXTENSION & Participation in extension trainings; Average number of times \\
\hline Extension access & ROAD & $\begin{array}{l}\text { Accessible road network for motor vehicles (cars, buses, and trucks...) } \\
\text { to villages, dummy variable: Yes = 1, No = 0 }\end{array}$ \\
\hline Road network &
\end{tabular}

Source: own processing, VHLSS

Table 1: Variables and their measurement.

\begin{tabular}{|c|c|c|c|c|c|}
\hline Hierarchical level/Variables & Obs. & Mean & S.D. & Min & $\operatorname{Max}$ \\
\hline \multicolumn{6}{|c|}{ Level 2 - Local government (Provincial level) } \\
\hline BUDGET & 1,226 & $19,570.73$ & $31,647.64$ & 1,199 & 176,263 \\
\hline \multicolumn{6}{|c|}{ Level 1 - Local communities (Communal level) } \\
\hline \multicolumn{6}{|l|}{ Dependent/Outcome variable } \\
\hline INCOME & 1,226 & $93,332.30$ & $47,671.33$ & 11,891 & 301,570 \\
\hline \multicolumn{6}{|l|}{ Independent variables } \\
\hline GEO & 1,226 & 0.54 & 0.45 & 0 & 1 \\
\hline GOVTPRO & 1,226 & 0.73 & 0.45 & 0 & 1 \\
\hline EXTENSION & 1,226 & 11.20 & 9.65 & 1 & 48 \\
\hline ROAD & 1,226 & 0.94 & 0.23 & 0 & 1 \\
\hline
\end{tabular}

Source: own processing, VHLSS 
or existing values and exert a constant effect on the dependent variable. On the other hand, random effects are considered as the continuous and randomly chosen values of a variable and influence variable impact on the dependent variable.

In terms of multilevel analysis, Intraclass Correlation Coefficient (ICC) is statistically significant to address the question whether we really need to conduct a multilevel analysis. Or in other words, if the sufficient variances represented in a higher level could justify the linear mixed approach. Besides, the reasons of using HLM is that the authors are believing that there might have a variability in individual and group levels (Boedeker, 2017) and a larger value of ICC will indicate a larger variability between levels. So, the ICC could be used to confirm the use of HLM in analyzing individual and group levels. In this case, we will conduct an empty model analysis (this model is similar to use One-way ANOVA model for variance component estimation) to obtain the variance components for ICC estimation. We have an empty 2-level multilevel modelling:

$Y_{i j}=\beta_{0 j}+\beta_{1 j} X_{i j}+r_{i j}$

With the random effect:

$Y_{i j}=\beta_{0 j}+r_{i j}$

Where $\operatorname{Var}\left(r_{i j}\right)=\sigma^{2}$ and group mean $\beta_{0 j}=\gamma_{00}+\mu_{0 j}$ (i.e. grand mean + a random quantity) assuming that uncorrelated with $r_{i j}$. Then, we have ICC definition as following:

$\operatorname{Corr}\left(Y_{i j} Y_{i^{\prime} j}\right)=\tau_{00} /\left(\tau_{00}+\sigma^{2}\right)$

Theoretically, there is no solid or "official" rules that could suppose how large the ICC value is enough for stating non-negligible nesting effect. However, a rule of thumb which is currently and widely being used says that about $10 \%$ (or double digits of ICC on percentage scale) of the total variance might represent a given level (Occhipinti, 2012) or as low as $5 \%$ could be considered as sufficient (Kreft and de Leeuw, 1998). Particularly, a two digits of ICC value could be considered as adequate for warranting a multilevel analysis because a single digit of ICC on percentage scale might denote that a single-level analysis could be more appropriate (Yu, 2012).

The result of variance component estimation in the Table 3 shows that the variances estimated at level 2 is 241,000,000 and 2,020,000,000 at level $1(\mathrm{p}<0.000)$. This makes the total variance equal to $2,261,000,000$ and the ICC $=0.11$. The ICC value implies that there are approximately $11 \%$ of the total variance in communal households' income represented at provincial levels. This is slightly higher than $10 \%$ which is a sign of no design effect. Therefore, the variance component is statistically significant.

In term of this research, we will construct a simple random-intercept model to answer the research question that to what extent the budget at provincial level can affect the households' income at communal levels. Basically, this multilevel model will help conceptualize lower-level units (the analysis units) as individuals and higherlevel units as groups (nested). This research would be a two-level hierarchical model with level-1 model (communes) and level-2 unit (provinces). In addition, this model is also called a within-unit model because it can estimate the effects of a single group context (Gill, 2003).

\begin{tabular}{|c|c|c|c|c|c|}
\hline $\begin{array}{l}\text { "Hierarchical level/ } \\
\text { Variables" }\end{array}$ & Obs. & Mean & S.D. & Min & Max \\
\hline \multicolumn{6}{|c|}{ Level 2 - Local government (Provincial level) } \\
\hline BUDGET & 1226 & 19570.73 & 31647.64 & 1199 & 176263 \\
\hline \multicolumn{6}{|c|}{ Level 1 - Local communities (Communal level) } \\
\hline \multicolumn{6}{|c|}{ Dependent/Outcome variable } \\
\hline INCOME & 1226 & 93332.30 & 47671.33 & 11891 & 301570 \\
\hline \multicolumn{6}{|l|}{ Independent variables } \\
\hline GEO & 1226 & 0.54 & 0.45 & 0 & 1 \\
\hline GOVTPRO & 1226 & 0.73 & 0.45 & 0 & 1 \\
\hline EXTENSION & 1226 & 11.2 & 9.65 & 1 & 48 \\
\hline ROAD & 1226 & 0.94 & 0.23 & 0 & 1 \\
\hline
\end{tabular}

Source: own processing 
To examine the relationship within lower level units, we proposed a simple regression model developed for each individual i with simple intercept as the following mixed model with one level-2 variable (BUDGET) and four level-1 variables (GEO, GOVTPRO, EXTENSION, and ROAD):

$$
\begin{aligned}
\text { INCOMEij } & =\gamma_{00}+\gamma_{01} \text { BUDGET }_{j}+\gamma_{10} \text { GEO }_{i j} \\
& +\gamma_{20} \text { GOVTPRO }_{i j}+\gamma_{30} \text { EXTENSION }_{i j} \\
& +\gamma_{40} \text { ROAD }_{i j}+u_{0 j}+r_{i j}
\end{aligned}
$$

In which,

$$
\begin{array}{ll}
- & \gamma_{00}+\gamma_{01} \text { BUDGET }_{j}+\gamma_{10} G E O_{i j}+\gamma_{20} G O V T P R O_{i j} \\
& +\gamma_{30} \text { EXTENSION } \\
& \text { fixed effects; and }
\end{array}
$$

- $u_{0 j}+r_{i j}$ plays the roles of random effects.

\section{Estimation method}

In the case of multilevel analysis models, they offer several options for estimation method such as Maximum Likelihood (ML) or Restricted Maximum Likelihood (REML). In general, ML and REML estimations provide a similar variance estimates, however, if they do not share this similarity, REML can produce a better estimate in multilevel analysis (Browne, 1998; Hox, 2010). In particular, ML estimators are relied on the usual likelihood theory, the notion of REML is to convert the response into a group of linear contrasts whose distribution is not affected by the fixed effects $(\beta)$ (StataCorp, 2015). Basically, the restricted likelihood can be formed from this linear contrast group by considering the distribution and helps minimize the problem of $\beta$. The unbiased characteristics of REML extend to all mixed models to deal with the unbalanced data. However, likelihoodratio (LR) tests fits which are used for comparing the goodness of two nested models based on REML are not appropriate because REML supposes to change the fixed effects specification and this could change the meaning of the mixed effects (Pinheiro and Bates, 2000). Hence, the researchers would apply the ML estimation method for the multilevel analysis to test whether the 4 predictors of households' INCOME at communal levels can reduce the within-province variance.

\section{Results and discussion}

The impact of government support on rural households' income

Generally, the mixed effect model is conducted with 1,226 observations in 34 groups. The results show that all variables have a positive impact on the dependent variable which is average households' income at the communal level. Among them, GEO, GOVTPRO, and EXTENSION are statistically significant at $1 \%$, while ROAD has a significant level of 5\%. Interestingly, the level-2 variable BUDGET from provincial governments positively exerts the households' income, but the extent of improvement is minor (Table 4).

Among the 4 level-1 variables, the geographical locations make the largest impact on rural households' income. This indicates that the income of rural communes in delta regions is approximately 12 million VND (equivalent to about 30\%) higher than the other regions (costal, mountainous, and midland regions). On the contrary, the coefficient of extension access shows the least impact on raising the income. Particularly, it signifies that technical training can help improve 2.8 million VND of rural households' income for every 1 training class people participating in. Another interesting aspect is that communes having government provision of economic development program and projects in the last 3 years have a larger income of 7.5 million VND (approximately $20 \%$ higher) compared with the other withoutsupport communes.

There is a striking feature that communes with car-accessible road to village levels could have an income of 10.3 million VND higher than those do not have. This indicates that investments in transportation facilities can make a huge difference in economic development in rural areas up to $26 \%$. An implication from this finding is that rural development programs should put more emphasis on transportation infrastructures which might not only increase the local households' income, but also help ensure a sustainable development of the income increase strategies.

Apparently, the level-2 variable of local government budget for the NRD program at communal levels has a positive impact on households' income. However, the 0.167 coefficient of BUDGET shows a weak influence on directly increasing rural families' income. This implies that each 1 billion expenditures of local provinces could only help improve 167 VND (equal to US\$ 0.008) for each household.

This can be explained that financial assistance through infrastructure, production facilities, and education only has an indirect impact on rural households' income. On the one side, most of the investments in infrastructure have been 
Mixed-effects ML regression

Group variable: PROVINCE

\begin{tabular}{|c|c|c|c|c|c|}
\hline \multicolumn{2}{|l|}{ Mixed-effects ML regression } & \multicolumn{3}{|c|}{ Number of obs. $=$} & 1226 \\
\hline \multirow[t]{6}{*}{ Group variable: PROVINCE } & & Number of gr & roups & $=$ & 34 \\
\hline & & \multicolumn{3}{|c|}{ Obs. per group: } & \\
\hline & & \multicolumn{3}{|l|}{$\operatorname{Min}=$} & 24 \\
\hline & & \multicolumn{3}{|l|}{ Avg. $=$} & 36.1 \\
\hline & & \multicolumn{3}{|l|}{$\operatorname{Max}=$} & 62 \\
\hline & & Wald $\operatorname{chi}^{2}(5)$ & \multicolumn{2}{|l|}{$=$} & 488.98 \\
\hline \multicolumn{2}{|l|}{ Log restricted-likelihood $=$} & Prob. $>$ chi $^{2}$ & \multicolumn{2}{|l|}{$=$} & 0.0000 \\
\hline INCOME & Coef. & Std. Err. & \multicolumn{2}{|r|}{$\mathrm{z}$} & $\mathrm{P}>\mathrm{Z}$ \\
\hline cons $\left(\gamma_{00}\right)$ & 39459.880 & 5975.073 & \multicolumn{2}{|r|}{6.60} & 0.000 \\
\hline $\operatorname{BUDGET}\left(\gamma_{01}\right)$ & 0.167 & 0.062 & \multicolumn{2}{|r|}{2.69} & 0.007 \\
\hline $\operatorname{GEO}\left(\gamma_{10}\right)$ & 12019.430 & 2738.633 & \multicolumn{2}{|r|}{4.39} & 0.000 \\
\hline $\operatorname{GOVTPRO}\left(\gamma_{20}\right)$ & 7540.864 & 2539.680 & \multicolumn{2}{|r|}{2.97} & 0.003 \\
\hline EXTENSION $\left(\gamma_{30}\right)$ & 2580.656 & 123.610 & \multicolumn{2}{|r|}{20.88} & 0.000 \\
\hline $\operatorname{ROAD}\left(\gamma_{40}\right)$ & 10270.020 & 5084.123 & \multicolumn{2}{|r|}{2.02} & 0.043 \\
\hline $\begin{array}{l}\text { Random-effects } \\
\text { Parameters }\end{array}$ & Estimate & Std. Err. & \multicolumn{2}{|c|}{$[95 \%$ Conf. } & Interval] \\
\hline \multicolumn{6}{|l|}{ PROVINCE: Identity } \\
\hline $\operatorname{Var}\left(\_\right.$cons $)\left(\tau_{00}\right)$ & 81600000 & 30900000 & & 800000 & 171000000 \\
\hline $\operatorname{Var}$ (Residual) $\left(\sigma^{2}\right)$ & 1470000000 & 60300000 & 1360 & 000000 & 1600000000 \\
\hline
\end{tabular}

Log restricted-likelihood $=\quad-14698.497$ Prob. $>$ chi $^{2}=$

\begin{tabular}{lrc}
34 & & \\
24 & & \\
6.1 & & \\
62 & & \\
98 & & \\
00 & & \\
& & \\
\hline & {$[95 \%$ Conf. } & Interval] \\
\hline 0.000 & 27748.950 & 51170.810 \\
0.007 & 0.045 & 0.289 \\
0.000 & 6651.807 & 17387.050 \\
0.003 & 2563.183 & 12518.540 \\
0.000 & 2338.385 & 2822.926 \\
0.043 & 305.325 & 20234.720 \\
\hline
\end{tabular}

Note: LR test vs. linear model: chibar2 $(01)=25.86 ;$ Prob $>=$ chibar2 $=0.0000$

Source: own processing

Table 4: The results of mixed effect model analysis.

made recently (but its benefits and impacts can only be estimated in the longer term. For example, infrastructure and production facilities like road, irrigation system, rice field designation might positively affect the income of families in rural areas. Moreover, some of the expenditure which is for local living conditions such as clean water supply, cultural halls, schools, or medical care stations will indirectly make an impact on rural households' income. Therefore, the coefficients of the other level-1 variables such as ROAD, GOVTPRO, and EXTENSION could play a complementary role in explaining the impact of BUDGET.

Comparison between the empty model and random coefficient model

On the results table, the lower part shows the estimated variance components (random effects) of the model. In the case of this research, we have only one random effect (a simple randomintercept model), therefore "Identity" will be the only possible covariance structure which stands for "Multiple of the Identity" having that all variances are equal variances for random effect and all of covariance are equal to 0 . In any case, the variance of the level-two errors is estimated as $81,600,000$ and the standard error is $30,900,000$. The var (Residual) demonstrates the estimated variance of the overall error term as 1,470,000,000.

In the estimation method section, the authors argued about the reasons of selecting ML method instead of REML to compare between variances of the empty and random coefficient model to test whether 4 predictors of households' INCOME at communal levels can reduce the within-province variance. The comparison between variances in the empty model and (One-Way ANOVA) and random coefficient model as the following formula:

$$
\begin{aligned}
& \frac{\sigma^{2}(\text { Empty model })-\sigma^{2}(\text { with predictors })}{\sigma^{2} \text { Empty model }} \\
& \quad=\frac{2,020,000,000-1,470,000,000}{2,020,000,000}=0.272
\end{aligned}
$$

Apparently, adding 4 variables as predictors of households' income can reduce the withinprovince variance by $27.2 \%$. Hence, the 4 predictors (GEO, GOVTPRO, EXTENSION, and ROAD) comprise $27.2 \%$ of the commune-level variance in the outcome. 


\section{Maximum Likelihood vs. Restricted Maximum Likelihood}

In the estimation method section, the authors have mentioned about Maximum Likelihood (ML) and Restricted Maximum Likelihood (REML) in HLM and the reasons why this paper applied ML instead of REML in its multilevel analysis. In order to discuss more about these methods, Boedeker (2017) indicated that REML should be employed when the variance estimates are significantly different between two methods and when the number of groups is small because REML could conduct a less-biased estimate of variances than ML. Nevertheless, how many groups could be considered as "small"? This paper discovered that, with the number of 34 groups, the difference of ME and REML is not significant. The variance estimates of $\mathrm{ML}$ and REML are $1,470,000,000$ and $1,480,000,000$ respectively. (See the appendix - Table 8 for the REML regression results). In this case, ML is strongly recommended to allow some model comparisons. From the findings of the paper, the authors recommend that HLM with less than 34 groups should apply REML for the estimation instead of ML to have less-biased estimates of variances.

\section{Conclusion}

The results of HLM point out that all of 4 level-1 variables and 1 level-2 variable positively influence on the households' income and are statistically significant. Especially, households in the delta areas have a higher income up to 12 million VND than those living the other areas, technical trainings can help improve 2.8 million VND of rural households' income for every 1 training class, communes having government provision of economic development projects in the last 3 years have a differential of 7.5 million VND compared with the other without-supported communes, and communes with car accessible road to village level could have a 10.3 million VND higher than those do not have. These results indicate that the program might help achieve the ultimate target to increase rural households' income at least 1.8 times between 2015 - 2020. However, the prioritized investments should increase in transportation infrastructures.

Despite the positive impacts of the NRD on rural households' income, there still exists another critical problem that is the gap between the convenient and inconvenient regions. In particular, the households in delta areas where have better conditions for agricultural farming or are usually close to the urban areas earning more up to 12 million VND (approximately 30\% higher) than the other regions (mostly remote, more difficult conditions for agricultural production). This poses a serious challenge to achieve the ultimate goal of improving rural households' income and shortening the gap between regions in spite of the government's incentives that poor and remote communes could receive a higher substantial assistance.

Although the budget support from provincial levels does not have a major impact on households' income, it still exerts an indirect influence on families' earning through investments in infrastructure (ROAD), education (EXTENSION), and economic development program and projects (GOVTPRO). These level results indicate that infrastructure and income generation models are the most important solutions to improve families' income which could help improve $26 \%$ and $20 \%$ respectively. It implies that development programs in developing countries should put more emphasis on transportation infrastructures which might not only increase local households' income, but also help ensure a sustainable development of the income increase strategies.

The empirical evidence can firmly answer the question that the local government budgets could effectively and positively influence on rural households' income through the NRD program. However, more in-depth analyses of the program's impacts on different aspects such as households' living conditions, local economy's development, and environment improvement need to be conducted to provide more detailed impacts of the NRD on rural communities in the socialeconomic development, political, and local security.

Corresponding authors:

Manh Hung Do

Southern Centre for Agricultural Policy and Strategy (SCAP)

Institute of Policy and Strategy for Agriculture and Rural Development (IPSARD)

3rd Floor, No. 12 Vo Van Kiet ST, District 1, Ho Chi Minh City (700000), Vietnam

Phone: +8490-9125885, Email: hungdoscap@gmail.com 


\section{References}

[1] Beaubien, J. M., Hamman, W. R., Holt, R. W. and Boehm Davis, D. A. (2001) "The application of hierarchical linear modeling (HLM) techniques to commercial aviation research", Proceedings of the $11^{\text {th }}$ annual symposium on aviation psychology, Columbus, OH: The Ohio State University Press [Online]. Available: https://www.researchgate.net/publication/241285890_the_application of_hierarchical_linear_modeling_hlm_techniques_to_commercial_aviation_research [Accessed: $\overline{5}$ Sep. 2018].

[2] Boedeker, P. (2017) "Hierarchical Linear Modeling with Maximum Likelihood, Restricted Maximum Likelihood, and Fully Bayesian Estimation", Practical Assessment, Research, and Evaluation, Vol 22, No. 2. [Online]. Available: http://pareonline.net/getvn.asp? $\mathrm{v}=22 \& \mathrm{n}=2$ [Accessed: 6 Sep. 2018]. ISSN 1531-7714

[3] Browne, W. J. (1998) "Applying MCMC methods to multilevel models", $\mathrm{PhD}$ dissertation, Department of Mathematics Science, University of Bath, the UK [Online]. Available: https://seis.bristol.ac.uk/ frwjb/materials/wbphd.pdf [Accessed 05 Sep. 2018].

[4] Cho, L.-J. and Kim, Y. H. (1991) "Economic development in the Republic of Korea: a policy perspective", East-West Centre, the University of Hawaii Press. ISBN 0-86638-131-7 [Online]. Available: http://hdl.handle.net/10125/22802 [Accessed: 07 Sep. 2018].

[5] Damas, P. and Israt R. M. (2004) "Vulnerability and Poverty: What are the causes and how are they related?", ZEF, Bonn University [Online]. Available: https://www.zef.de/fileadmin/downloads/ forum/docprog/Termpapers/2004_3a_Philip_Rayan.pdf [Accessed 05 Sep. 2018].

[6] Dempster, A. P., Laird, N. M. and Rubin, D. B. (1977) "Maximum likelihood from incomplete data via the EM algorithm", Journal of the Royal Statistical Society, Series B, (Methodological), Vol. 39, No. 1, pp. 1-38. [Online]. Available: https://www.jstor.org/stable/2984875 [Accessed: 7 Sep. 2018]. ISSN:1467-9868.

[7] Desimone, L. M., Porter, A. C., Garet, M. S., Yoon, K. S. and Birman, B. F. (2002) "Effects of Professional Development on Teachers' Instruction: Results from a Three-year Longitudinal Study", Educational Evaluation and Policy Analysis, Vol. 24, No. 2., pp. 81-112. DOI 10.3102/01623737024002081.

[8] Economic Committee (2016) “Báo cáo kết quả thục hiện Giám sát Chuoong trình Nông thôn mói (NTM)" (in Vietnamese), Ủy Ban Kinh Tế của Quốc Hội (the Economic Committee of the Vietnam National Assembly) [Online]. Available: http://quochoi.vn/uybankinhte/giamsat/Pages/giam-sat. aspx?ItemID=537 [Accessed: 10 Sep. 2018].

[9] Garner, L. C. and Raudenbush, W. S. (1991) "Neighborhood Effects on Educational Attainment: A Multilevel Analysis", Sociology of Education, Vol. 64, No. 4, pp. 251-262. E-ISSN 19398573, ISSN 00380407. DOI 10.2307/2112706.

[10] Gill, J. (2003) "Hierarchical linear models", In Kimberly Kempf-Leonard (Ed.) "Encyclopedia of social measurement". New York: Academic Press. ISBN 978-0-12-369398-3.

[11] GSO (2010) “Tổng điều tra dân số và nhà ở tại Việt Nam năm 2009: Các kết quả chủ yếu” (in Vietnamese), Tổng cục thống kê Việt Nam (General Statistics Office of Vietnam) [Online]. Available: https:/www.gso.gov.vn/default.aspx?tabid=512\&idmid=5\&ItemID $=9812$ [Accessed: 5 Sep. 2018].

[12] GSO (2016) "Vietnam Household Living Standard Survey (VHLSS) in 2002, 2004, 2006, 2008, 2010, 2012, 2014", General Statistic Office of Vietnam [Survey Data].

[13] Hox, J. J. (2010) “Quantitative methodology series. Multilevel analysis: Techniques and applications", $2^{\text {nd }}$ ed., New York, NY, US: Routledge/Taylor \& Francis Group, pp. 217, ISBN 978-0-203-85227-9.

[14] Huta, V. (2014) "When to Use Hierarchical Linear Modelling", The Quantitative Methods for Psychology, Vol 10, No. 1, pp. 13-28. ISSN 2292-1354. DOI 10.20982/tqmp.10.1.p013. 
[15] Keon-Hyung, L., Sang-Chul, P., Jung-Won, P. and Seunghoo, L. (2013) "Medicaid inpatient costs and nested structural analysis using a hierarchical linear modeling (HLM) approach", Health Services and Outcomes Research Methodology, Vol. 13, No. 2-4, pp 157-173. E-ISSN 1572-9400, ISSN 1387-3741. DOI 10.1007/s10742-013-0108-3.

[16] Kreft, I. G., and De Leeuw, J. (1998) “Introducing multilevel modeling”, Thousand Oaks, CA: Sage. ISBN 0-7619-5141-5. DOI 10.4135/9781849209366.

[17] Lee, V. E., Dedrick, R. F. and Smith, J. B. (1991) "The Effect of the Social Organization of Schools on Teachers' Efficacy and Satisfaction", Sociology of Education, Vol. 64, No. 3, pp. 190-208. E-ISSN 19398573, ISSN 00380407. DOI 10.2307/2112851.

[18] Ma, X. and Klinger, D. A. (2000) "Hierarchical Linear Modelling of Student and School Effects on Academic Achievement", Canadian Journal of Education/Revue Canadienne De L'éducation, Vol. 25, No. 1, pp. 41-55. E-ISSN 19185979, ISSN 03802361. DOI 10.2307/1585867.

[19] Manh Hung, D., Viet Hung N., Phuong Thu N. T., Kim Thoan N., Tung Lam, D., Sang Chul, P. (2016) "New Rural Development and Hierarchical Governance in Vietnam", The Journal of Korea Balanced Development Studies, Korea Research Institute for Balanced Development, Yeungnam University, Vol. 7, No. 2, pp. 1-23. ISSN 1975-6542.

[20] Marks, H. M. and Printy, S. M. (2003) "Principal Leadership and School Performance: An Integration of Transformational and Instructional Leadership", Educational Administration Quarterly, Vol. 39, No. 3, pp. 370-397. DOI 10.1177/0013161X03253412.

[21] Occhipinti, S. (2012) "Mixed Modelling using Stata", Griffith Health Institute Workshop for GSBRC, July 2012 [Online]. Available: http://www.griffith.edu.au/_data/assets/pdf_file/0011/439346/ Stata_mixed_intro-1.pdf [Accessed: 16 Aug. 2017].

[22] Osborne, J. W. (2000) "Advantages of hierarchical linear modeling", Practical Assessment, Research, and Evaluation, Vol. 7, No. 1, pp. 1-3. [Online]. Available: http://ericae.net/pare/getvn. asp? $=7 \& n=1$ [Accessed: 05 Sep. 2018]. E-ISSN 1531-7714.

[23] Paterson, L. and Goldstein, H. (1991) "New Statistical Methods for Analysing Social Structures: an introduction to multilevel models", British Educational Research Journal, Vol. 17, No. 4., pp. 387-393. E-ISSN 1469-3518, ISSN 0141-1926. DOI 10.1080/0141192910170408.

[24] Pinheiro, J. C. and Bates, D. M. (2000) "Mixed-Effects Models in S and S-PLUS", Springer-Verlag, pp. 82-93, ISBN 978-0-387-22747-4. DOI 10.1007/B98882.

[25] Raudenbush, S. and Bryk, A. (1986) “A Hierarchical Model for Studying School Effects”, Sociology of Education, Vol. 59, No. 1, pp. 1-17. E-ISSN 19398573, ISSN 00380407. DOI 10.2307/2112482.

[26] Raudenbush, S. W., Rowan, B. and Kang, S. J. (1991) "A Multilevel, Multivariate Model for Studying School Climate with Estimation Via the EM Algorithm and Application to U.S. HighSchool Data", Journal of Educational and Behavioral Statistics, Vol. 16, No. 4, pp. 295-330. DOI 10.3102/10769986016004295.

[27] Raudenbush, S. W. and Bryk, A. S. (2002) "Hierarchical linear models: Applications and data analysis methods, second edition", Newbury Park, CA: Sage. ISBN-13 978-0761919049.

[28] Rice, N. and Leyland, A. (1996) "Multilevel Models: Applications to Health Data", Journal of Health Services Research \& Policy, Vol.1, No. 3, pp. 154-164. DOI 10.1177/135581969600100307.

[29] Rice, N. and Jones, A. (1997) "Multilevel models and health economics", Health Economics, Vol. 6, No. 6, pp. 561-575. [Online]. Available: https://www.york.ac.uk/media/che/documents/ papers/technicalpapers/CHE\%20Technical\%20Paper\%204.pdf [Accessed: 07 Sep. 2018].

[30] Rudengren, J., Huong, N. T. L, and Wachenfelt, A. (2012) "Rural Development Policies in Vietnam: Transitioning from Central Planning to a Market Economy", Institute for Security and Development Policy. Stockholm Paper. [Online]. Available: http://isdp.eu/content/uploads/images/stories/isdp-main-pdf/2012rudengren-rural-developmentvietnam.pdf [Accessed: 07 Sep. 2018]. ISBN 978-91-86635-34-3. 
[31] Sang-Chul, P., Kwak Chang Gyu, and Kwon Sung Wook. (2012) "Residential Development and Hierarchical Governance: Multifamily Housing and Multilevel Analysis", The Korean Journal of Policy Studies, Vol. 27, No. 2, pp. 1-22. [Online]. Available: http://s-space.snu. ac.kr/bitstream/10371/79013/1/01_Sung-Wook\%20Kwon.pdf [Accessed: 11 Sep. 2018]. ISSN 1225-5017.

[32] Sooyoung, P. (2009) "Analysis of Saemaul Undong: a Korean rural development programme in the 1970s", Asia-Pacific Development Journal, Vol. 16, No. 2, pp. 113-140. [Online]. Available: https://www.unescap.org/sites/default/files/apdj-16-2-5-Park.pdf [Accessed: 7 Sep. 2018]. ISSN 1020-1246.

[33] StataCorp (2015) "Stata: Release 14", Statistical Software. College Station, TX: StataCorp LP.

[34] The World Bank (2018) "World Bank Open Data of Gross Domestic Product (GDP) (current US\$)" [Online]. Available: https://data.worldbank.org/indicator/NY.GDP.MKTP.CD?locations=VN [Accessed: 9 Sep. 2018].

[35] Woltman, H., Feldstain, A., Mackay, J. C. and Rocchi, M. (2012) "An introduction to hierarchical linear modeling", Tutorials in Quantitative Methods for Psychology, Vol. 8, No. 1, pp.52-69. ISSN 1913-4126. DOI 10.20982/tqmp.08.1.p052.

[36] Yu, R. (2012) “Introduction to Multilevel Modeling", Training course materials for the workshop help on 8/7/2012 [Online]. Available: http://odin.mdacc.tmc.edu/ ryu/materials/MultilevelModeling part1.pdf [Accessed: 5 Sep. 2018]. 


\section{Appendix}

$\begin{array}{llr}\text { Number of obs } & = & 1226 \\ \mathrm{~F}(5,1220) & = & 113.57 \\ \text { Prob }>\mathrm{F} & = & 0 \\ \text { R-squared } & = & 0.318 \\ \text { Adj R-squared } & = & 0.315 \\ \text { Root MSE } & = & 39460\end{array}$

\begin{tabular}{l|rrr} 
Source & SS & df & \multicolumn{1}{c}{ MS } \\
\hline Model & 884220000000 & 5 & 176840000000 \\
\hline Residual & 1899700000000 & 1220 & 1557100000 \\
\hline Total & 2783900000000 & 1225 & 2272600000
\end{tabular}

\begin{tabular}{lrrrrrr}
\hline INCOME & \multicolumn{1}{c}{ Coef. } & \multicolumn{1}{c}{ Std. Err. } & \multicolumn{1}{c}{$\mathrm{z}$} & $\mathrm{P}>\mathrm{z}$ & \multicolumn{1}{c}{$[95 \%$ Conf. } & \multicolumn{1}{c}{ Interval $]$} \\
\hline _cons & 37783.970 & 5554.201 & 6.800 & 0.000 & 26887.130 & 48680.820 \\
BUDGET & 0.167 & 0.036 & 4.660 & 0.000 & 0.097 & 0.237 \\
GEO & 13210.550 & 2275.186 & 5.810 & 0.000 & 8746.837 & 17674.260 \\
GOVTPRO & 5910.342 & 2553.170 & 2.310 & 0.021 & 901.252 & 10919.430 \\
EXTENSION & 2603.712 & 117.805 & 22.100 & 0.000 & 2372.589 & 2834.834 \\
ROAD & 12427.610 & 4901.058 & 2.540 & 0.011 & 2812.170 & 22043.040 \\
\hline
\end{tabular}

Source: own processing

Table 5: Conventional regression analysis.

\begin{tabular}{l|cc}
\hline Variable & VIF & $1 /$ VIF \\
\hline GOVTPRO & 1.02 & 0.981 \\
EXTENSION & 1.02 & 0.984 \\
GEO & 1.01 & 0.987 \\
BUDGET & 1.01 & 0.992 \\
ROAD & 1.00 & 0.996 \\
\hline Mean VIF & 1.01 \\
\hline
\end{tabular}

Source: own processing

Table 6: Multicollinearity test.

Breusch-Pagan / Cook-Weisberg test for heteroskedasticity

Ho: Constant variance

Variables: fitted values of INCOME

$$
\begin{aligned}
& \operatorname{chi}^{2}(1)=368.43 \\
& \text { Prob }>\text { chi }^{2}=0.0000
\end{aligned}
$$

Source: own processing

Table 6: Multicollinearity test. 
Mixed-effects REML regression

Group variable: PROVINCE

$\begin{array}{lr}\text { Number of obs. }= & 1226 \\ \text { Number of groups }= & 34 \\ \text { Obs. per group: } & \\ \text { Min }= & 24 \\ \text { Avg. }= & 36.1 \\ \text { Max }= & 62 \\ \text { Wald chi }{ }^{2}(5)= & 483.97 \\ \text { Prob. }>\text { chi }^{2}= & 0.0000\end{array}$

Log restricted-likelihood $=$

-14659.057 Prob. $>$ chi $^{2}$

\begin{tabular}{|c|c|c|c|c|}
\hline INCOME & Coef. & Std. Err. & $\mathrm{z}$ & $\mathrm{P}>\mathrm{Z}$ \\
\hline cons $\left(\gamma_{00}\right)$ & $39,540.150$ & $6,029.397$ & 6.56 & 0.000 \\
\hline $\operatorname{BUDGET}\left(\gamma_{01}\right)$ & 0.167 & 0.065 & 2.58 & 0.010 \\
\hline $\operatorname{GEO}\left(\gamma_{10}\right)$ & $11,961.41$ & $2,770.604$ & 4.32 & 0.000 \\
\hline GOVTPRO $\left(\gamma_{20}\right)$ & $7,600.832$ & $2,545.458$ & 2.99 & 0.003 \\
\hline EXTENSION $\left(\gamma_{30}\right)$ & $2,580.742$ & 124.156 & 20.79 & 0.000 \\
\hline $\operatorname{ROAD}\left(\gamma_{40}\right)$ & $10,168.790$ & $5,106.353$ & 1.99 & 0.046 \\
\hline Random-effects Parameters & Estimate & Std. Err. & {$[95 \%$ Conf. } & Interval] \\
\hline \multicolumn{5}{|l|}{ PROVINCE: Identity } \\
\hline $\operatorname{Var}\left(\_\right.$cons $)\left(\tau_{00}\right)$ & $91,700,000$ & $34,500,000$ & $43,900,000$ & $192,000,000$ \\
\hline $\operatorname{Var}\left(\right.$ Residual) $\left(\sigma^{2}\right)$ & $1,480,000,000$ & $60,600,000$ & $1,360,000,000$ & $1,600,000,000$ \\
\hline
\end{tabular}

Note: LR test vs. linear model: chibar2 $(01)=25.86$; Prob $>=$ chibar2 $=0.0000$

Source: own processing

Table 4: The results of mixed effect model analysis. 
